\title{
Early Anglo-Saxon community
}

Each early Anglo-Saxon cemetery was unique, the product of multiple agents working at different times, in different spaces and with different visions. Each grave was the end result of a funeral situated within specific chronological and community circumstances, influenced by social agents and their relationships to the deceased and to each other. In many ways each grave was the product of both a social context and of interpersonal relationships. Inhumation graves were cut into the soil and cremation pyres were built by hand. Together some participants had to lower the body into the ground or raise it onto a pyre. These were co-operative actions, they created or recreated bonds and reinforced existing relationships. As a result, a mortuary event included an emotional element in which objects, bodies, relationships and memories intertwined and occupied physical spaces. It was in this context that the dead were situated within the contemporary community narrative, the result of a series of negotiations that adopted locally contingent mortuary technologies, material cultures and spatial locations and which fitted with the expectations of mourners and other participants.

This final chapter brings together the other chapters and situates them within the historical context. It includes two case studies, Morning Thorpe and Lechlade, to demonstrate how the syntax, grammar, metre and intonation of the cemetery can be used to start building a holistic picture combining spaces and people. This study is a multi-dimensional interpretation because it explores space and chronology, and multi-scaled because it looks from gravegoods to individual identities, as well as to local and regional narratives. In particular, this chapter is interested in family, household and kinship, themes that have cropped up throughout this book. It situates the detailed explorations presented in each of the previous chapters alongside an exploration of Anglo-Saxon historical information, with a particular emphasis on contemporary (seventhcentury) law codes. After all, the people buried in these sites were alive 
when the laws were first spoken about and written down, and as a result they were constructed from the same Zeitgeist, the same blood, sweat and attitudes of the contemporary cultural context.

\title{
Kinship and household
}

One of the key funerals described in the epic poem Beowulf is that of Hildeburh's kin. There was a feud between her father and her husband. Presumably she was married as part of a peace pledge to resolve an earlier phase of the feud, but the situation erupted again and in the ensuing battle both her brother and her son are killed while fighting on opposite sides at the hall of Finn, her husband, who was killed after the joint funeral of his son and his brother-in-law (Sayer et al., 2009; Sebo, 2015; Sebo, pers. comm.). This dual funeral was designed by Hildeburh as an expression of her grief and also of her anger at the conflict. Hildeburh ordered a pyre to be built for her brother, Hnæf, and then placed her son beside him so they were cremated together. The poet's emphasis is on the construction of the pyre and how it allows for a public display of the couple, which focuses Hildeburh's emotional distress:

\author{
Here-Scyldinga \\ betst beadorinca was on bael gearu. \\ at paam ade wos epgesyne \\ swatfah syrce \\ (The war-Scylding, \\ The best battle-warrior [Hnæf] was prepared on the pyre, \\ At the funeral pile he was easily seen, \\ His tunic covered in blood) (Sebo, 2015)
}

The circumstances dictated the nature of the ritual and its emphasis; it was designed by a wife and mother, with a focus on her brother. Had this mortuary drama been prepared by Hildeburh's daughter-in-law it might have looked quite different. Rather than being cremated in the clothes they died in, they might have been dressed in new clothes and with identifiable gravegoods. The visibility of the injuries they inflicted on each other was important to emphasise loss and grief:

\footnotetext{
hafelan multon.

bengeato burston ðonne blód cetspranc,

láðbite líces. líg ealle forswealg, gaesta gifrost, para ðe paer guð fornam

bega folces. (Beowulf, lines 1120b-1124a)
} 
(Heads melted.

Wounds burst open, then blood gushed out, from the body's hate-bites. Fire swallowed everything The greediest guest - those who were taken by the battle, from both sides.) (Sebo, 2015)

According to this description, marriage may have been a somewhat dangerous and unsuccessful device to settle a feud between two kindred (Rosenthal, 1966). In this funeral from Beowulf, a grandson had fought on behalf of his maternal grandfather, but died by the hand of his uncle. Uncle and son were cremated together.

Jack Goody (1983: 230) describes Anglo-Saxon society as egooriented rather than ancestor-oriented because he suggests that a person's kindred were important for support in feuds. Indeed, the state of feud is heavily cited by scholars of Anglo-Saxon social institutions because it contributed to one of the largest bodies of literature considering kindred. In the collection of wergild (the fine for killing a person) the role of direct kin varied according to circumstance, and it is likely that the recovery of this compensation fell to a wider group. The early eleventh-century document Textus Roffensis defined the extent of kindred involved in the surety for wergild payment; it states that for a twelve-hundred man (a nobleman whose wergild was set at 1,200 shillings) twelve men were to act as surety, eight from the paternal kinsmen and four from the maternal kinsmen. It is because of this that Loyn (1974: 204) argued 'we are clearly dealing with a society where great emphasis is placed on the individual and his household and the inner kin', because both paternal and maternal kindred were involved.

In the Textus Roffensis however, it was not a given that these kinsmen would support the slayer. In Edmund's earlier code (AD 939-49), concerning the blood feud, it affirms this:

[1.1.] If, however, the kindred abandons him, and is not willing to pay compensation for him, it is then my will that all that kindred is to be exempt from the feud, except the actual slayer, if they give him neither food nor protection afterwards. (Whitelock, 1955: 391)

These documents allow the kin to abandon the agitator and, provided they give him no support in the form of food and protection, then he alone bears the responsibility for the feud and its compensation. Notably:

[1.] If henceforth anyone slays a man, he himself to bear the feud, unless he can with the aid of his friends within twelve months pay compensation at the full wergild, whatever class he [the man slain] may belong to. (Whitelock, 1955: 391) 
It is interesting that the term 'friends' (freond or frynd) is used here, and that this group was able to aid in the payment of compensation, demonstrating that by at least the tenth century the payment of wergild was not restricted to kin groups. Nevertheless, the details of these frynds are not specified and so may refer to less-defined kinship arrangements (Lancaster, 1958b: 375). These later texts were a form of social engineering intended to dismantle powerful kin alliances and shift responsibility for conflict resolution from the family to the institutions of kingship. Another early eleventh-century document, 'The ordinance of the bishops and reeves of the London district' (VI Athelstan), states:

[8.2.] And if it happens that any kindred is so strong and so large, ... we are to ride thither with all our men with the reeve in whose district it is.

[8.3.] And also we are to send in both directions to the reeves and request help from them of as many men as may seem to us suitable in so great a suit, so that the guilty men may stand in greater awe on account of our association; and we are all to ride thither and avenge our injury and kill the thief and those who fight with him and support him, unless they will desert him. (Whitelock, 1955: 389)

This is contradictory, in that it demonstrates the state's intention to control kindred, but it also proves how strong those kindred could be if reeves from several directions were potentially needed for support (Lancaster, 1958a; 1958b; Bloch, 1962; Loyn, 1974; Goody, 1983; Murray, 1983; Drew, 1988).

If later-Saxon England saw the deliberate decline in the power of the elite kindred, undermined by the emerging power of the Church and the King, it has been assumed that early Anglo-Saxon England was a 'Golden Age' of the kin and, indeed, that the laws did not need to mention their importance because they were taken for granted. But this assumption probably reveals more about evolutionary approaches to historical anthropology than it does about early Anglo-Saxons. It is therefore worth considering some of these laws.

Some of the earliest laws we have date from the seventh century. In the Laws of Æthelbert, King of Kent (recorded AD 602-3) it stated that 'If anyone kills a man he is to pay as an ordinary wergild 100 shillings' (Whitelock, 1955: 358; Oliver, 2002: 53/67), of which twenty shillings were to be paid at the open grave, and if the killer left the land his kin were responsible for paying half the wergild. There is no indication that the kin should pay any of the wergild unless the guilty man ran away and there is, significantly, no indication of who was present at the open grave of the deceased. In the Laws of Ine, King of Wessex (recorded AD 688-94), if a foreigner was slain then a third of his wergild would 
go either to his son or to his kinsmen (Whitelock, 1955: 366), the rest to the king, and if he (the foreigner) had no kinsmen then it was to go his gesith (lord). Importantly, this blood-price was paid first to his son or his household, then to the kinsmen and finally to his lord. It was not until the later Laws of Alfred (recorded AD 871-99) that we start to see evidence of the sharing of wergild payments between kin: '[8.3.] if her [of a nun stolen from a convent] child is killed, the share of the maternal kindred is to be paid to the King; the paternal kindred are to be given their share' (Whitelock, 1955: 375). This is interesting in that, as the child is illegitimate, it cannot inherit from its father, but it still requires the protection of the paternal kindred. There are further definitions within the Laws of Alfred:

[30 (27).] If a man without paternal kinsmen fights and kills a man, and if then he has maternal kinsmen, those are to pay a third share of the wergild [and the associates a third]; [for the third part] he is to flee.

[31 (28).] If anyone kills a man so placed, if he has no kinsmen, he is to pay half to the King, half to the associates. (Whitelock, 1955: 377-8)

Here again there is reference to people other than the kin - the 'associates' - though there is also reference to the maternal kin. But perhaps, rather than seeing this as evidence of legal bilateralism (Lancaster, $1958 \mathrm{~b})$, we should be cautious. The written statement of this responsibility tends to imply that it was not assumed, suggesting that the maternal kin did not routinely take responsibility for their daughter's children or her husband.

As we saw earlier in Æthelbert's law, the payment of wergild was due at the graveside, which suggests that an individual present at that grave would receive payment, or at least part of it. If we assume that this means literally at the graveside, and is not a reference to the time by which the compensation must be paid, the funeral becomes paramount. The funeral was when a community might redefine itself following the loss of one or more of its members (Metcalf and Huntington, 1991). At the graveside that relationship was defined and redefined, and division of the wergild might be as much a ritualised action, separated into parts by those present, as it was a legal responsibility. However, this also seems a peculiar clause, for surely the most dangerous (or insulting) or simply problematic time for a slayer or their kin to redress this death was when the family had gathered to remember their loss and their pain. As Lisi Oliver argues, this part payment forced the pronouncement of murder, and its settlement, at the most emotive time possible and at precisely the point where blood feud was likely to break out (Oliver, 2002: 97). As the example of Hildeburh's kin illustrates, it is likely that these 
feuds took place between entwined groups among whom the boundaries of relatedness and obligation were not always clear. In other words, it is likely that the murderer was known to the kindred, and was even part of it or its extended network.

Another source of information that the law codes dealt with might be described as family law (Drew, 1988). In these documents, marriage was a surprisingly secular business, conducted between families to the satisfaction of the woman and her kindred and, interestingly, marriage did not seem to interfere with a woman's wergild because she retained the status of her father (Loyn, 1974: 206). Nonetheless, it was clearly important to create and maintain a relationship with affinal kin, who had their own distinct terminology, for example, father-in-law (sweor) and mother-in-law (sweger) (Lancaster, 1958a: 247-8). This terminology identified the maternal kin group, suggesting that they had a role post-marriage but perhaps also a different social function. Lorraine Lancaster argued that they remained less important than the paternal kindred (Lancaster, 1958a: 248).

Equally, marriage was not the only institution of union, and concubines may have been commonplace until the Conversion, when they were discouraged by the Church (Ross, 1985). A concubine was legally a member of the man's household, and this state may suggest a degree of intra-kin or incest coupling where marriage would otherwise have been forbidden (Clayton, 2008: 136; Goody, 1983; Ross, 1985). The early Church's desire to quell these unions is undeniable, but the extent of incest or concubinage remains unclear (Clayton, 2008). By contrast, Æthelbert's seventh-century Kentish laws listed penalties for adultery but omitted incest (Oliver, 2002), whereas the seventh-century canons of Theodore, Archbishop of Canterbury, had provision for dealing with homosexuality, incest, sex between siblings and mother-child incest (Gravdal, 1995; Frantzen, 2008). Strikingly, these two sources illustrate a difference in how household practice collided with an emerging Christian morality.

One aspect of marriage that was discussed in detail was the breakdown of marriage. Æthelbert's Law devoted a few clauses to dealing with the inheritance of a wife (Oliver, 2002: 79). These suggested that, if a woman had a healthy baby she would be entitled to half of the household goods should her husband die first. If she left her husband and took the children, she was also to have half of his goods, but if she wished to take another husband the inheritance was split between mother and child. They also indicate that if she was childless her paternal kinsmen would obtain her goods and the 'morning-gift' (the gift from her husband on the morning following the marriage). These laws, numbered 76, defined a woman's inheritance, but only if 
she bore children; they were more concerned with her husband's kin and protecting his inheritance. The Laws of Hlothhere and Eadric, Kings of Kent (they ruled jointly between AD 679 and 685), provided a clause stating that a widow should return to her kindred with the child, leaving someone from his father's kin to maintain the child's property until he was ten years old (the law refers to the child as he) (Oliver, 2002: 129). These laws imply that a woman's role in a man's household was not necessarily permanent, and that her family remained paramount in her welfare and her life.

Ine's Law also described the situation of a widow and child:

[38.] If a husband and a wife have a child together, and the husband dies, the mother is to have her child and rear it; she is to be given six shillings for its maintenance, a cow in summer, and ox in winter; the kinsmen are to take charge of the paternal home, until the child is grown up. (Whitelock, 1955: 367)

This clause, like those of Hlothhere and Eadric, was concerned with maintaining the husband's inheritance, and providing for the child's protection while the child remained in the care of his/her maternal kinsmen. It is noteworthy that there were no clauses for the maintenance of a child if its mother died, because the father's inheritance remained with the paternal kindred. This shows that the matrilineal kin only had a secondary kinship association with the child. It also suggests that the paternal kindred took priority in legal guardianship of inheritance, and it implies a degree of patrilocality among the social elite. In all of these cases it seems that the woman has travelled for marriage, and then returned to her family to rear her child following divorce or the death of her husband.

Extant Anglo-Saxon wills provide further evidence of male and female family responsibilities; a woman's obligation may have been to see her father's wishes completed (Crick, 2000). Women may not always have been independent of their father's or husband's wishes, but they were not totally dependent agents either and did not always follow the directions of men. Indeed, the will of Ælfflæd (will XV: 39-43, AD 1000-02) completes the bequests of her father, Ælffgar (will II: 103-8, AD 941-51), and although she honoured many of his land grants, some of which also passed from her sister, Æthelflæde (will XIV: 35-7, AD 971-91), her actions were not always in line with her father's wishes as outlined in his will (Whitelock 1930). Ælfflæd had many estates 'from her ancestors' which were not mentioned in the wills of her sister or father, and she also held many estates which should have passed directly from her sister to a monastic foundation but did not: Cockfield and Ditton, Suffolk, are 
two examples. Her estate at Totham, Essex, was supposed to go to a religious foundation at Mersea, Essex, but instead she split it up and the forest went to Stoke in her bequest. Waldingfield was supposed to pass to a monastery in a place called Crawe but Ælfflæd bequeathed it to one called St Georges instead. These actions were not those of a passive female, whose function was to carry out her father's wishes, and they show that women ran estates consisting of many households and were able to make executive decisions. Ælfflæd had the influence to alter the passage of land (Crick, 2000).

\section{Households}

Family was not the only domestic scenario, and references to households are a part of Anglo-Saxon language. For example, David Pelteret has argued that the word inbired was used to refer to the sociological household in a societal and not a legal sense. In this case in-is a prefix which denoted the household association, inpeow therefore being a slave associated directly with the household (Pelteret, 1995: 43). Terms like this defined a household slave, meaning there were also non-household slaves not situated within the immediate household but still under the charge of the household head. Even so, it was the household and the state of being responsible for it which conferred status.

A household was a separate entity from family and may have consisted of servants; for those with some means, this might have included a reeve, a priest or military people who were not related or only distantly related to the core family. The early Law of Æthelbert supports this and refers to a serving woman (cup-bearer) of a nobleman, as well as other female slaves of second and third class (Oliver 2002: 67). The compensation to the owner if a man slept with an enslaved woman depended on the slave's status and the status of their owner. Further, Æthelbert's Law states: '26. If anyone kills a freeman's loaf eater [dependant], they are to pay six shillings compensation' (Oliver, 2002: 69). Hlothhere and Eadric's Laws 1 and 2 referred to the responsibility a person had for their servants; they indicate that if an unfree person (a slave, or household dependant) killed a freeperson of rank then their owner was responsible for paying the compensation and handing over the killer (Oliver, 2002: 127). If a servant killed another servant then the owner had to pay for that action (Æthelbert's Law, clause 76, Oliver 2002: 79). Ine's Law, clauses 19 and 22, referred to a geneat, who was a tenant or dependant, and was described by Whitelock as a member of the household; this geneat may have had a high wergild value, suggesting that not all members of a household were slaves or servants (Whitelock, 1955: 366). Also in Ine's Law a gesith, who was a member 
of the household and was of noble birth, had their own reeve, a smith and a nanny, as well as unfree workers (Whitelock, 1955: 371). The household of a person of high status could include individuals of many different functions, but a royal household might have had bondspersons who were themselves of substantial rank by virtue of having their own households. Effectively, important or wealthy households would have had satellite households associated with them. A reeve, a priest or a smith, for example, might have had his or her own marriage, servants and slaves.

As we have seen, responsibility for a household lay with the head of that household, but legally its members may not always have been responsible for the actions of the head of the household, witness Ine's Law:

[7.] If anyone steals without his wife and children knowing, he is to pay 60 shillings fine.

[7.1.] If, however, he steals with the knowledge of all his household, they are all to go into slavery. (Whitelock, 1955: 365)

These ordinances of Ine suggest that the immediate family were not responsible for the crimes of another unless they had become party to them.

Anglo-Saxon England had a legal system of compensations and some of these may tell us about the function of household. Æthelbert's Laws defined the compensation for offences against a person's house. Number 79 dealt with a man taking a 'maiden' or woman by force (Oliver, 2002: 79, 106). The head of the house was responsible for applying the fine, and clauses and responsibilities like this make it hard to see the servants or slaves described in these laws as simply objects (Pelteret, 1995: 42). Therefore, while a household may have consisted of the immediate family, partner or concubines, children and possibly otherwise unconnected/unmarried kindred, it will also have included individuals who contributed to the production of food and clothing, childcare and the maintenance of land, as well as metalworkers and skilled labourers. Some of these individuals may have had their own families, and even their own households consisting of family, free associates and servants.

Many of these legal descriptions are contemporary with the early Anglo-Saxon cemeteries, and so if they described family situations, and household responsibilities, it is not unreasonable to assume that we might see some evidence of these complexities within the archaeological record. 


\section{Space, place and material culture}

Each early Anglo-Saxon cemetery appears different: they had varied overall forms, they were different sizes and they contained different assemblages of material culture. Nonetheless, the communities that used and returned to these sites drew from a comparable repertoire of mortuary syntaxes to subdivide the cemetery. In doing this they created and reproduced a number of underlying but comparable narratives that defined the organisation of space. How this narrative changed is visible in the evolution of mortuary space. The users of the cemetery created, structured and shared in a constantly changing semiotic knowledge. This book has shown that early Anglo-Saxon cemeteries were chaotic and lived spaces, that each grave was the product of different agents acting under dissimilar influences, and that each agent made a unique contribution to the funeral; because of this inherent fluidity, cemetery spaces encapsulated and reflected the contemporary context. In short, they can be understood today because they were meant to be understood by mortuary participants while they were in use. Cemetery aesthetic was used locally to communicate at a cultural level; it provided the physical space to support the narrative discourse of a particular community, and even though each space and each narrative was different it is likely that people from different communities, near or far, would have understood the messages and narratives embedded there. To these unfamiliar participants some aspects of the site would seem outlandish, even alien, while others would have been familiar or even comforting.

Within early Anglo-Saxon cemeteries, materials and spaces had multiple meanings, and people concurrently expressed diverse and disparate identities, which created a muddle of messages. As a result, archaeological investigation cannot isolate just one factor, like social status, for example. What was social status but the product of a series of relationships between people? A head of a household was not that without servants to work the land, or a family to offer legal support. Likewise, a slave without a master was not a slave. Individuals were not singular entities but were entangled within a social complex. These relationships empowered the mortuary actants with differential agency in creating a material expression that was the product of a range of contextually contingent conceptual tools unique to that place and those people. Importantly, mortuary expression was communication, which produced leitmotifs that were meant to be understood because they communicated shared cultural experiences. Early Anglo-Saxon cemeteries were dynamic and complex places. Yet they are often depicted in reconstruction drawings as insipid, not colourless per se, but empty of 
emotion or involvement - individuals are spaced apart, inert and not interacting, bodies separated (Williams, 2009).

Instead, each funeral event was different; the dead were dissimilar people, situated within social relationships which were played out by participants. The graves were earthen and cut through the soil by hand. Together some participants had to lower the body into the ground and in doing so their bodies mingled with that of the deceased; they blended with each other and with the soil. These people laid out arms and legs, arranged clothing, faces, heads, hands and feet. To place objects in the grave the mortuary participants must have also climbed into it, and sat or lain next to the body. This experience involved physical and emotional interactions, creating an intimacy between people living and dead (Figures 6.1 and 6.2).

Despite these unique experiences, each mortuary event contained similarities: the participants had relationships, and in these interactions their social world was reproduced though communication and collaboration. Their individual attitudes towards status, gender, age and kinship were shaped by relationships created or defined by existing social structures in the form of agreed canons. These principles had been renegotiated as these were confirmed or challenged by social situations, creating new semiotic knowledge shared between participants. Objects were symbiotic to this situation because they were an aesthetic essential and part of these layered and textured experiences. Cultural perspectives towards gender, for example, added to a mixture of other forces, which included kinship, age, status or family and which might have acted on people's behaviour or perceptions. The social world was not a fixed entity, but changed and evolved in a state of constant negotiation, and this renegotiation and dynamism are evidenced by the variation within and between each cemetery.

As described above, the sixth-century cemetery resulted from an aggregate of multiple perspectives and within this space the syntax of the cemetery could change over time. In a second phase in the later-sixth and seventh century, the southern and eastern coasts of England witnessed a new phase which was probably partly inspired by Merovingian burial practice. Rows of graves gave the impression of order, but in both phases cemetery arrangement was augmented by existing topographies in the form of old features - barrows, Roman buildings or earlier ditches - or new ones such as key burials or central locations within the cemetery.

Thinking of these spaces as either monocentric or polycentric, based on the clustering of graves, is useful but simplistic. As this study has shown, it was only the smallest sites that included just one technology to organise the space. Visible features divided cemeteries into areas, 


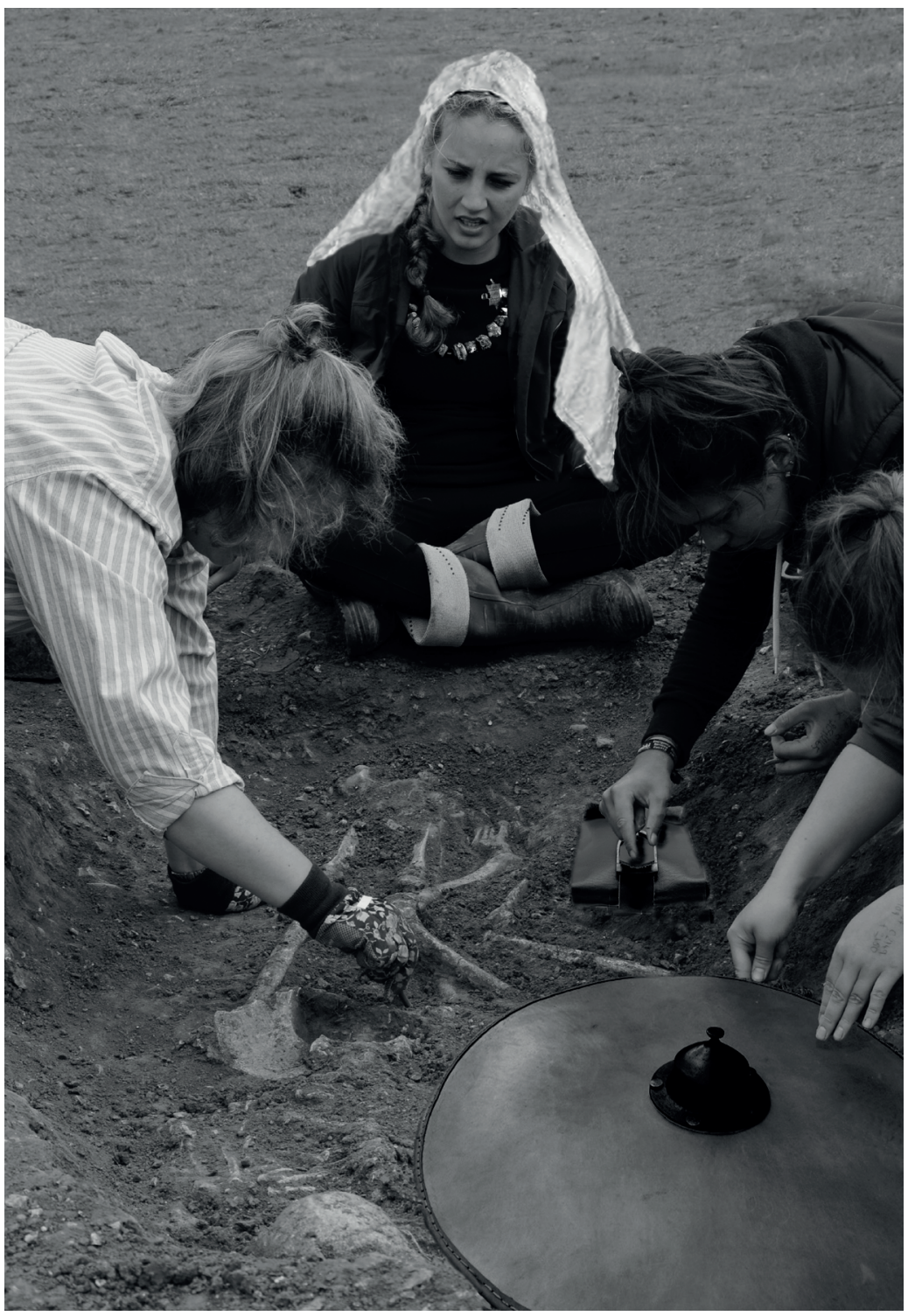

Figure 6.1 A reconstruction based on archaeologists working at Oakington in 2014. Kayla, Alison, Shanice and Anna are excavating a sixth-century grave. Gravegoods and Anglo-Saxon clothing have been added to this image to resemble the creation of a burial, providing a dynamic experiential reconstruction. Just like the archaeologists working here, the team of people who laid out the burial and the gravegoods would have had to climb into the grave, and would have got on their hands and knees to lay out the body and gravegoods. Like the team here, led by Kayla at the foot of the grave, there may have been hierarchies of people instructing and negotiating the arrangement. 


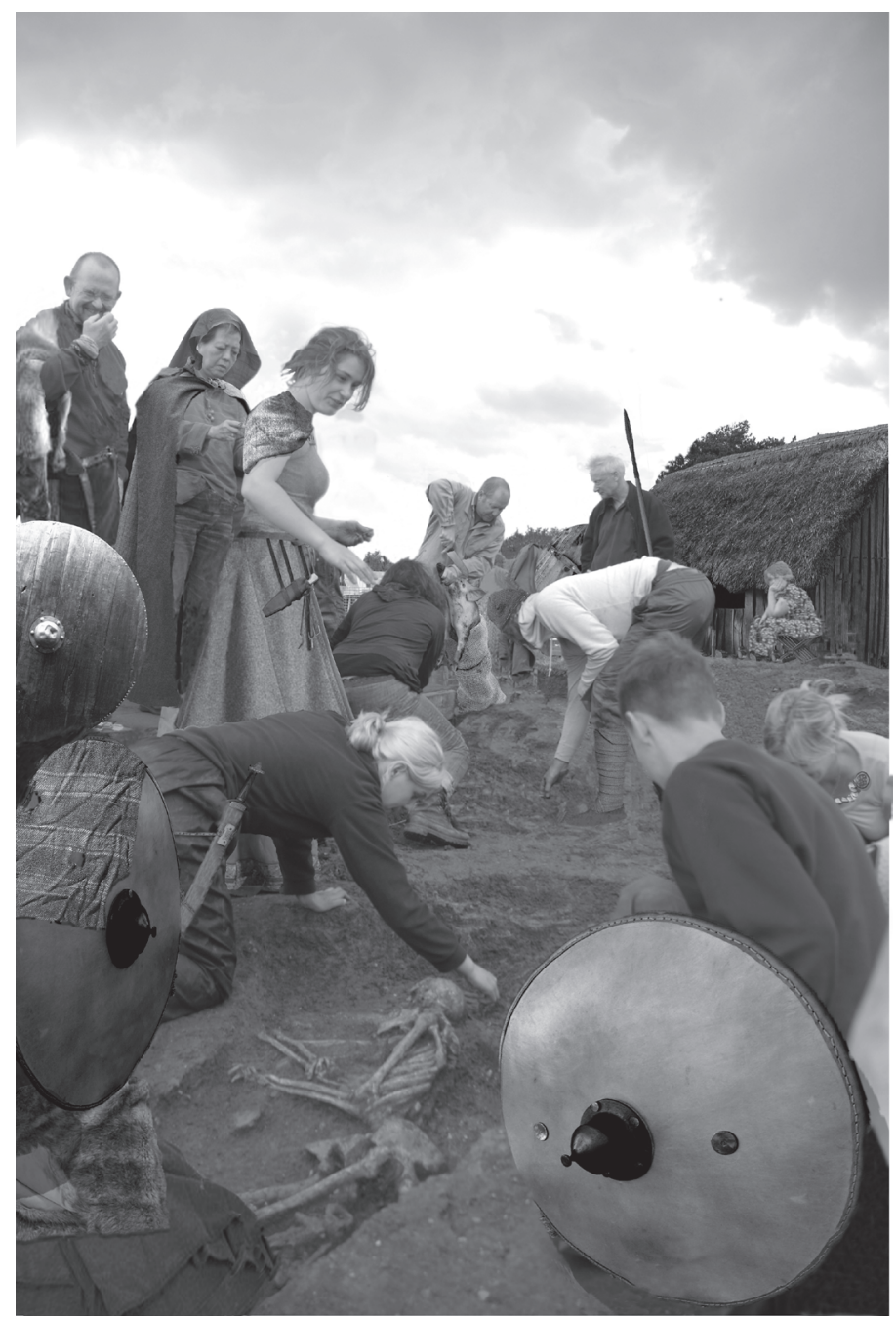

Figure 6.2 A busy excavation scene. This reconstruction is based on an open day at Oakington in 2012. It includes site directors, excavation supervisors, excavators, members of the public and my father, with a spear. Each of these people's experiences and knowledge of the archaeology here was different. Like Figure 6.1, this image conveys the interaction of people engaged in multiple different tasks. In the foreground the body is laid out, some people are interacting with the corpse and negotiating the objects to place within the burial. To the left of the grave, visitors look on, while in the middle a group of people go over the soil preparing to use it to build a mound over the body. Behind them a man kills a pig to prepare a feast, and others watch the whole scene away from the grave, or from the nearby settlement. This image conveys the physicality of the mortuary drama, and illustrates a multitude of ways that people could participate in the funeral events, at different levels and with different degrees of engagement or knowledge. 
groups or plots. This included clusters of graves that could be observed and defined by spatial statistics, or by changes in the density of burial, which defined specific groups of graves either between or within clusters. Alternatively, the cemetery architects might use contrasting orientations, as at Berinsfield, Petersfinger, Apple Down and Great Chesterford, to define separate groups or to visually identify outliers dividing spaces; or orientation might have been used to distinguish a few burials within a larger plot, as also seen at Great Chesterford. The choice whether to cremate or inhume also contributed to the shape of burial space, as with Spong Hill, Springfield Lyons, Apple Down and Andover; but, just like orientation or density, cremation could also distinguish or identify an individual's grave or a small group of graves within a larger burial area.

How a corpse was dressed, which objects went into the grave or were withheld, how a corpse was prepared, whether it was cremated or inhumed, and how a corpse was laid out were all locally mediated decisions based on the expectations of mortuary participants. The result was a continually negotiated expression which depended on who was alive to participate. Cemetery chronology might allow us to see this cadence or metre, allowing us to explore the biography of cemetery space and with that the specific groups or identities within it (Hines and Bayliss, 2013: 560). At Orpington a single grave provided a central point around which generations of subsequent weapon graves, child graves and cremations were located. Equally, at Oakington and at Dover Buckland, the emphasis of several burial areas was around key individuals marked by small barrows. This pattern was also seen in several later-sixth- and seventh-century sites, which may have had more uniformity, for example, St Peters, Lechlade and Finglesham. Other cemeteries contained plots with higher densities of graves, creating a concentric pattern. In comparison, at Morning Thorpe, West Heslerton, Apple Down and Deal, or the core areas of plot F at Dover Buckland and plot $\mathrm{C}$ at Wakerley, burials were densely packed. The same place may have been used to inter key individuals for generation after generation. But not all burial areas contained this chronological focus: configuration $B$ burials at Apple Down, plots H-I, B or Di at Dover Buckland and the excavated plot at Sewerby all used a horizontal stratigraphy, where contemporary graves were positioned together and adjacent to their predecessors, so that the burial space moved over time. These plots had no obvious central core (Figure 6.3). A number of smaller sixth-century burial plots - at Dover Buckland (plots L, E or G), the westerly graves at Orpington or the dispersed graves at West Heslerton and Polhill - did not seem to have a chronological character. This difference was part of an attitude to burial space and mortuary commemoration, and these attitudes towards cemetery space seem to have differed between different burial areas, and 

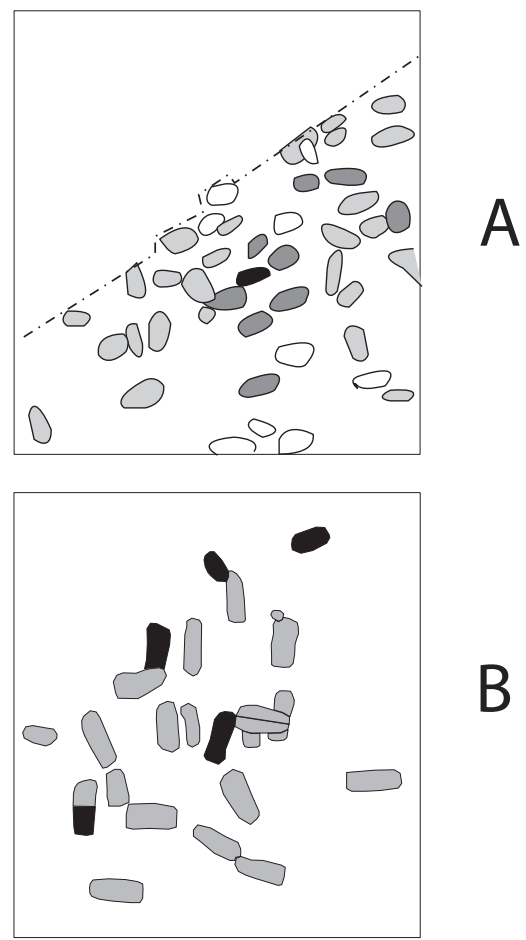

B

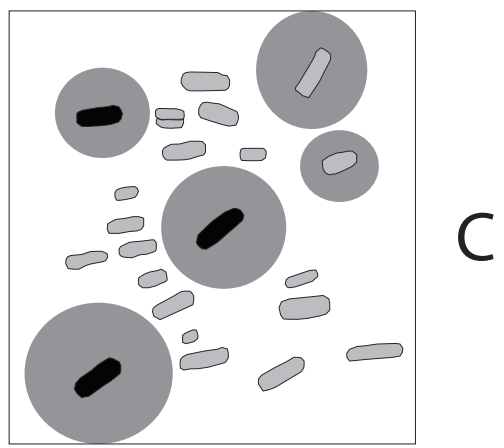

Figure 6.3 Different types of core graves within plots: the darker the grave, the more gravegoods were identified. Plot A was a focused plot with a central core of furnished burials surrounded by well-furnished darker burials and lighter less well-furnished burials - this example is West Heslerton. Plot B was a dispersed core from Lechlade, and $\mathrm{C}$ consisted of a series of barrow burials with satellite graves from Finglesham. These burial forms seem to indicate that there were alternative attitudes towards the dead, with different communities/groups valuing different forms of mortuary expression, even within the same cemetery space. 
between groups of people with different lifeways. Indeed, as we saw in Chapter 3, each of these burial plots at Dover Buckland had a different style. Some were densely packed, some were marked by barrows, while others used external features or had internal divisions along age or gender lines.

This differential attitude was defined by significant variations within the cemetery spaces. These included a whole host of attitudes towards the dead. But, notably, attitudes seem to have been contained within two basic types of cemetery: those with two or more similarly sized, broadly equal groups with similar lifeways; and those cemeteries with a burial area that had some internal structuring, for example a core area, as well as a spectrum of other areas without similar structure. In the examples discussed here, these less-structured areas also contained those individuals with a higher risk of trauma and with less overall mortuary wealth. Importantly, these patterns were visible within and between groups within the cemetery, and not just between types of graves. For example, it was not possible to see patterns within weapon graves because the placement of a weapon within a grave was dependent on a host of different decisions, many of which may have been about the personal situation of the deceased. Their age, gender, identity, cause and time of death, and who was alive at the time of that death, directly affected how they were seen and interacted with. This is important, because within specific burial areas it was the type of grave that shared key biological characteristics like diet, morphologically similar dentition or correspondence in height which showed similarities.

Indeed, the most stable post mortem communities, namely those that showed less internal variation, also had similar patterns across the life of the cemetery, where those individuals who suffered least from exposure to the risk of trauma had the most homogeneity among their tooth and height metrics. Collectively, these groups may have expressed the greatest wealth, even if individually graves may not have been furnished. Many cemeteries contained one plot that was wealthier than the others, for example; Wakerley, Apple Down, West Heslerton, Great Chesterford and Holborough. Within these examples the wealthy graves were positioned in central zones or core areas which included similar, often more densely packed, graves that created an aesthetic focus. These core areas within plots or burial areas seem to have been multigenerational. The women of these same areas also may have included the wealthier graves, for examples those buried with brooches, but they had much more biological variety between them than the male graves. The women seem to have been more heterogeneous in their origin, but it was a group of people with specific social attitudes who returned to a cemetery generation after generation and created an area with a high 
density of burials, with groups, clusters or rows of graves. Importantly, it was the attitude towards burial - location, orientation, chronology and not just the wealth within it that provides us with the best evidence for social difference.

As we saw at Leighton Buzzard III, Great Chesterford, Wakerley and Finglesham, there was hierarchy to group affiliation, and some plots contained core burials which created mnemonic regimes for regional display. The males within these areas may have been of similar height and may have shared comparable lifeways. Other plots, or groups of graves, did not exhibit the same biological similarity, and did not employ a core area for burial. These local community arrangements seem to imply that there was one primary group with one or two subsidiary groups, differentiated because they had different attitudes towards the dead. These groups may also have had subtly different life experiences. These secondary or tertiary plots employed separate burial areas, and may have placed less emphasis on gender, or life stages or childhood, and as a result they employed less internal structuring within the mortuary spaces. Along with less organisation there seems to have been less focus on funerary narratives for retelling. These systems created and reinforced differences in attitude highlighted and underpinned by the lived experience. These attitudes were not just towards the treatment of ancestors or the dead, but included attitudes towards the expression and communication of gender and age. Importantly, at sites like West Heslerton, Broadway Hill, Winterbourne Gunner, Lyminge II, Westgarth Gardens, Berinsfield, Deal, Bargates, Fonaby and Snell's Corner, there was evidence of gender separation, highlighting male or female characteristics in central places in specific groups of burials. These recognisable structures drew on local and cultural tropes, and it was these attitudes, not the presence of objects, which served to distinguish the elite individuals from each generation.

In this volume, the syntax of the cemetery, the grammar of the grave, the metre of burial practice and the biological evidence for interconnectedness have been reviewed separately. In this final chapter it is worth visiting two important and complex sites to illustrate how these elements come together. Morning Thorpe was an extremely important cemetery where, like Deal and Wakerley, there were very strong patterns in the distribution of material culture that correlated with the spatial arrangement of the site, and as a result corresponded with differences in attitude and lifeways. Lechlade has been discussed before, but it is one of the most complex cemeteries in the corpus of early Anglo-Saxon sites. Here, spatial data correspond with mortuary ritual and height data across the long duration of the fifth to later-seventh century. At both cemeteries the evidence points to the origination of the sites along family 
and household lines, where attitudes towards burial corresponded with social groups with different lifeways. Male kinship, wealth and ancestry mattered more to some than to others. It was these social groups that correspond with the early Anglo-Saxon family at the core of the households described in the historical literature.

\section{Morning Thorpe: the material repertoire}

Morning Thorpe was excavated in 1974 as a rescue excavation and recorded 320 inhumations and nine cremations (Green et al., 1987). Kenneth Penn and Birte Brugmann (2007) suggested some evidence for the clustering of the graves into groups that included males, females and the smaller graves of children, but not to the extent that would justify describing them as clusters of a nuclear family variety. Indeed, the graves at Morning Thorpe were extremely tightly crowded but not homogeneous, with statistically significant clustering around $1.5 \mathrm{~m}$. As a result, there were four groups of graves, with a narrow but nonetheless visible gap separating them; notably, the central two groups had a particularly high density of graves (Figure 6.4). As at Wakerley, these four groups (from left to right: A, B, C and D) were also associated with subtly different material culture. Notably, group A and D graves were more likely to contain long knives, with a blade length of over $10 \mathrm{~cm}$, with ten associated with group D and twelve with $\mathrm{B}$, and just two examples each associated with groups A and C. The same is true of belt buckles that have copper-alloy loops, which were found in group B and D burials, with only one example in group C (Chadwick Hawkes and Dunning, 1961, type 1 buckles; Penn and Brugmann, 2007: 32; Figure 6.5). Girdle hangers were more common in area $\mathrm{B}$ with ten examples, and only three in group $\mathrm{C}$ and two in group $\mathrm{D}$; burials in area $\mathrm{C}$ were more likely to have a bucket or 'tub' suggesting a ritual unique to this group. These are fascinating distributions, and perhaps they show that there were slightly different ways to dress the dead among each group, with a memory of different methods passed separately within each group between generations.

Perhaps though the most remarkable thing about the Morning Thorpe cemetery was the spatial groupings among the stamped pottery vessels that were found in more than one grave (Penn and Brugmann, 2007: 40). These groupings paralleled the spatial groups identified with the Ripley's K-test and subsistent kernel density plot. These groupings principally correspond with plots B and C. Stamps 'Ih', 'Ik', 'Iic' and 'Ivd' were found in plot B and 'Ia' was primarily found in plot $\mathrm{C}$ with some examples in plot B (Figure 6.6). Interestingly, plot D contained a mixture of stamps found more frequently in plots $\mathrm{B}$ and $\mathrm{C}$, whereas 


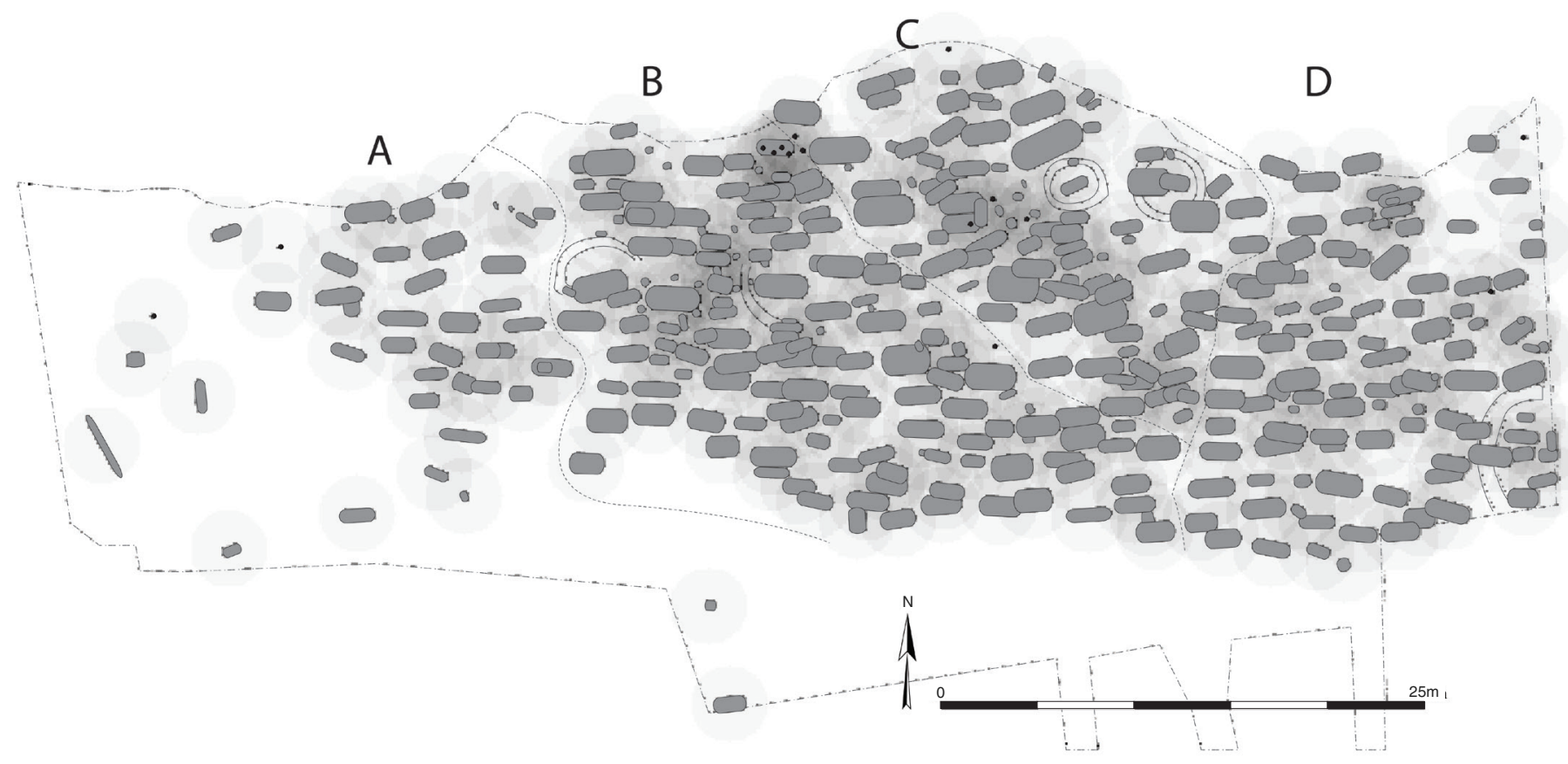

Figure 6.4 Morning Thorpe, Norfolk: kernel densities illustrated at $2 \mathrm{~m}$. There was a narrow, but nonetheless visible, gap separating each of these plots, illustrated by the dashed lines. Notably, the central two groups, B and C, had particularly high-density concentrations of graves. 


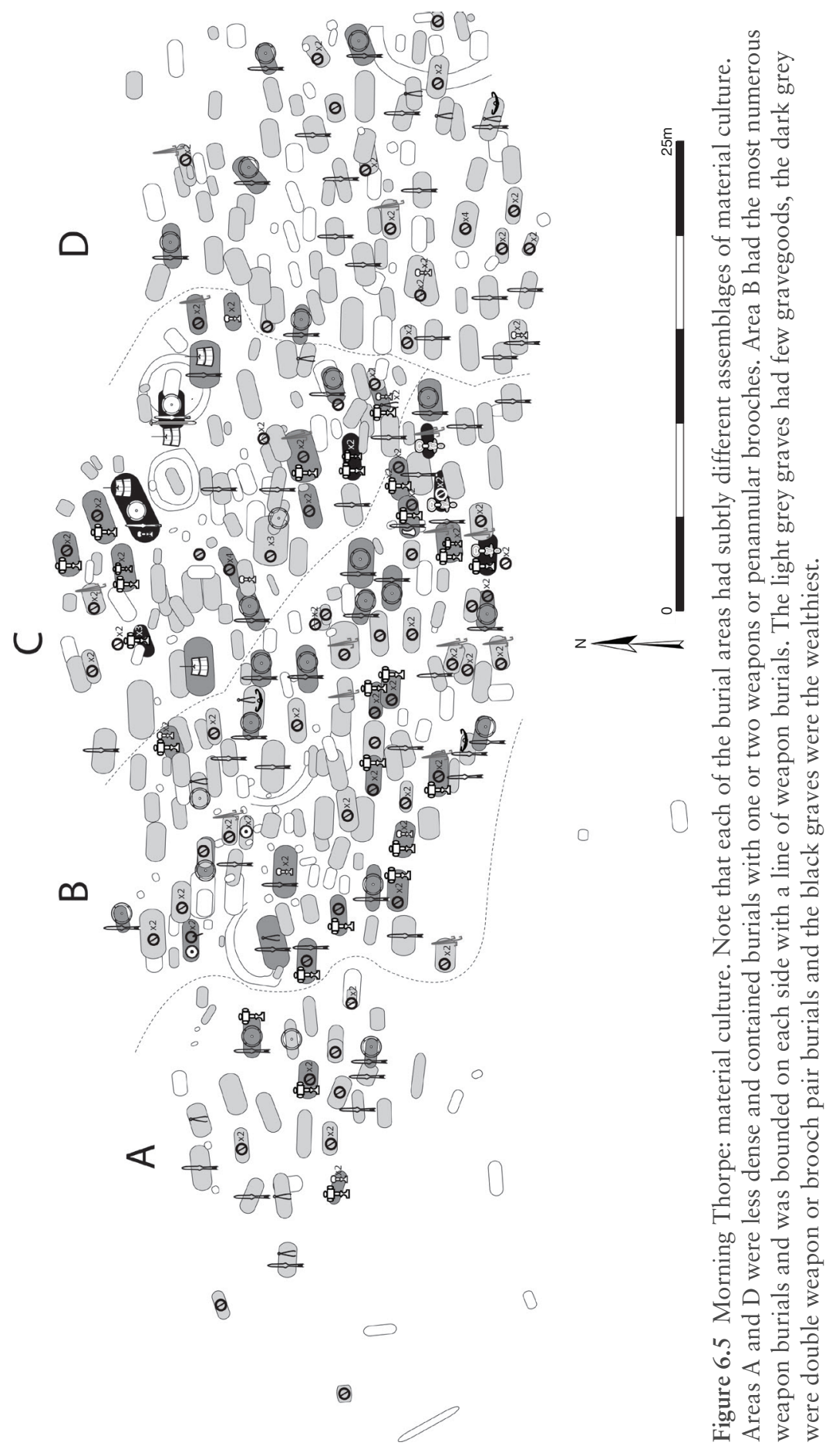




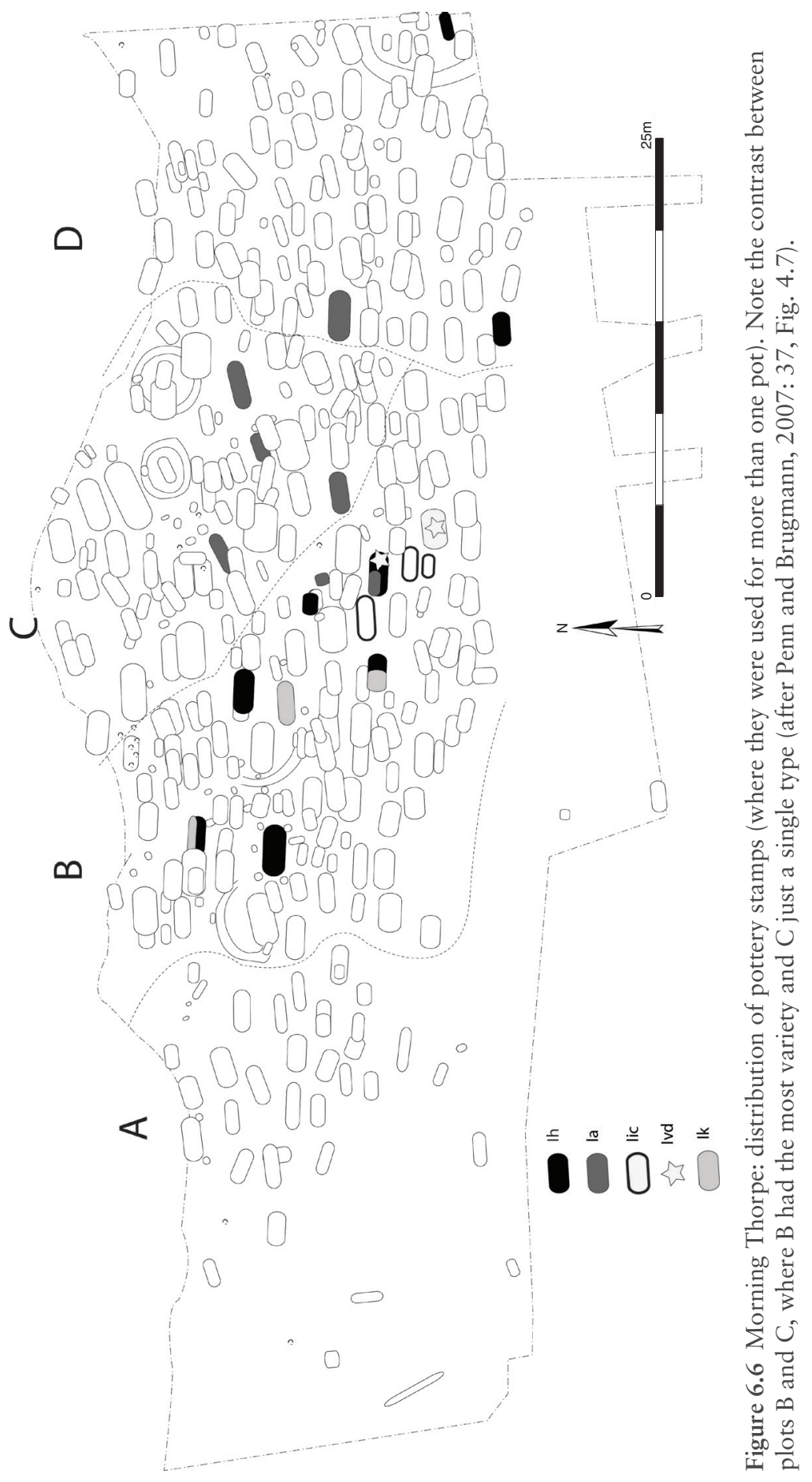


plot A contained no parallel stamps despite having eight pottery vessels; the sole stamp found in plot A was not paralleled in the other three. Nowell Myres (1937: 391) rather unfairly suggested an 'unimaginative potter' or 'housewife' may have used the same stamps to mark family pots, evidenced at Brighthampton (Oxfordshire) by two identical pots from adjacent graves. Similar stamps were also shared between cemeteries; Myers (1937), for example, also points out similar vessels from Lackford and West Stow (both in Suffolk). Indeed, the uniform use of prints on pottery has been suggested as the result of a clan use of stamps (Hills, 1978: 148), and at Spong Hill stamp groups A, B and C had noticeable spatial distributions linked with the cemetery chronology (Hills and Lucy, 2013: 217-18).

The distribution of material culture at Morning Thorpe was complex, and there were clear differences between the types of object found within each plot. Morning Thorpe is one cemetery, and so the individuals placed within it were interconnected, and probably shared a similar regional perspective. For the most part the funerary rite was constant, annular or penannular brooches for women and spears for men, but even here there were different funerary traditions evident throughout the site. Plots $\mathrm{B}$ and $\mathrm{C}$ were by far the wealthiest and contained the majority of burials with either weapon sets or brooch sets. B and C also had the more elaborate graves, for example, grave 35 with spearhead, shield boss, shield studs, knife, buckles, pottery vessel and tub. Grave 35 was also a double burial with a small-long brooch and wrist clasps (Figure 6.5). Importantly then, just as with Apple Down (see Chapter 1), the funerary ritual varied between these different areas. Plots B and C were the most marked in their difference and were also the wealthiest plots, and each used different strategies for their internal arrangement. In plot $\mathrm{B}$, the majority of wealthy weapon sets or brooch sets were located around the edges of the group, defining its boundaries; and the highest density of burials was found between barrow graves 157 and 170, within the boundary defined by the majority of the weapon and brooch burials. Indeed, the smaller graves, presumably infants and children, were found in the interior of this row of graves. Only the later graves in plot $\mathrm{B}$, in the south-eastern corner (phase FB, AD 530/550-650, Penn and Brugmann, 2007: fig 5.12), were notably wealthy, with three great square-headed brooches.

Plot $\mathrm{C}$ was organised very differently and had a number of wealthy graves throughout its interior, with many less wealthy inhumations found buried around them. Many of these burials may have had small barrows erected over them, marking them as central points (Figure 6.7). Two of these graves, 38 and 277, were evident because of ring ditches, whereas burials 2, 200, 208, 233, and 333 had satellite inhumations 


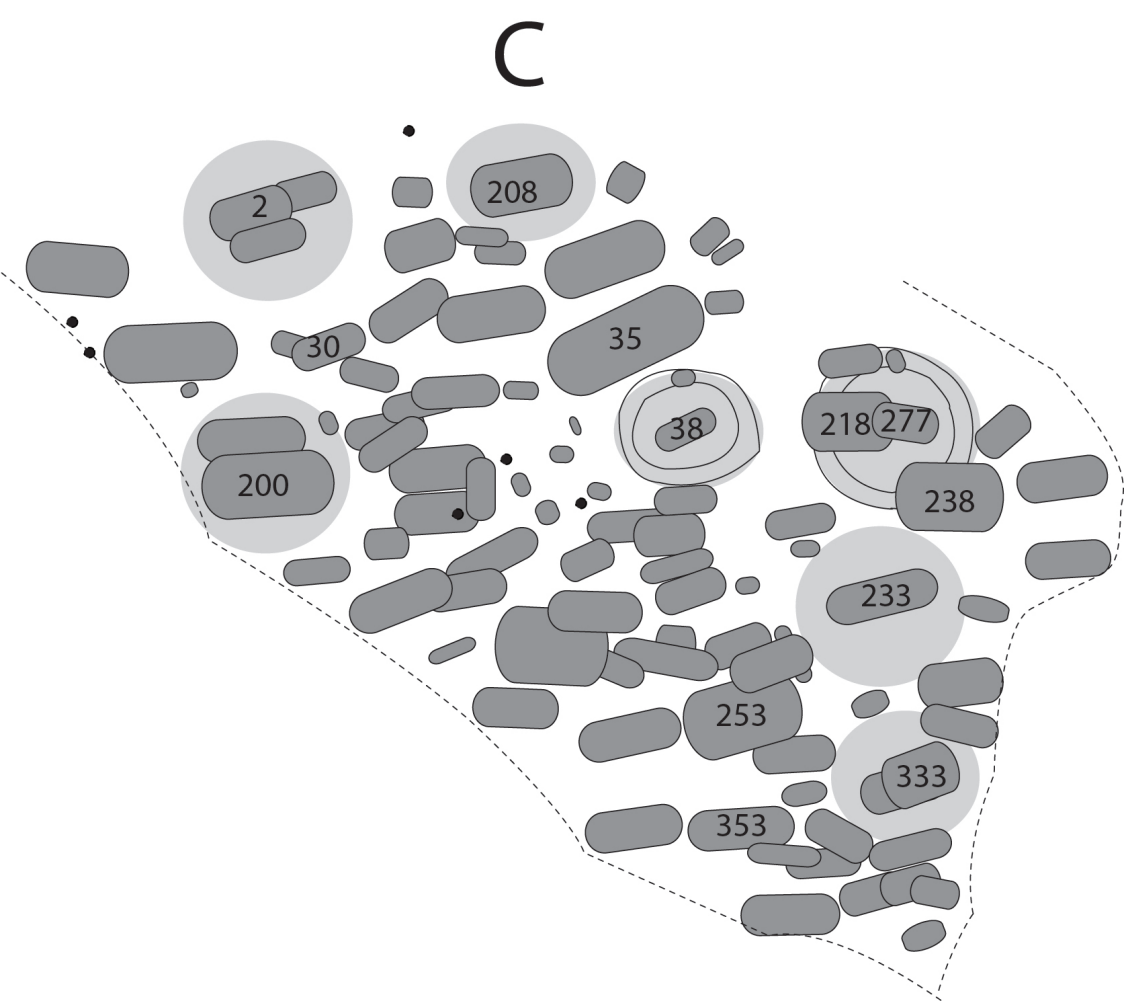

Figure 6.7 Morning Thorpe: barrows in plot C. The light-grey circles illustrate the location of barrows, based on the presence of satellite graves that appear to circle around them. Graves whose date is discussed are also marked.

that seem to have traced around a now-lost barrow; unfortunately neither grave 38 nor 277 was easily datable. The smaller graves were of infants and children, and were positioned centrally to the burial area. Of the datable graves, 35 and 238 were MA2 (AD 510-60/70), whereas 218 was MB (AD 560-650); female graves 30 and 353 were both FA1 (c. AD 480-500) and 253 was FA2 (AD 500-50) (Penn and Brugmann, 2007: 69). These dates imply that the wealthy barrow burials belong to different generations, and so plot $\mathrm{C}$ was organised around a series of individual graves creating successive central points around which later graves were placed. Indeed, the highest density of graves in this plot was found between the wealthy barrow burials.

Plots A and D did not contain the wealth of plots B and C, and no structuring was evident within plot A. However, plot D seems to have had a row of graves oriented N/S on its western edge. These graves define the plot's edge or boundary and visually separate it from plots $\mathrm{B}$ and $\mathrm{C}$. Internally, plot D had a row of gendered graves positioned 
diagonally across it SW/NE, with spear burials on the western side and annular/penannular brooch burials on the eastern. On the southern edge of this row were four spear and four annular/penannular brooch burials. These were divided, with males on the western side and females on the eastern. Each of these plots had different attitudes towards, or local traditions behind, their origination and perhaps these were the product of family traditions, a way of preparing and interring the dead which was transmitted though practice and storytelling within different family groups. Unfortunately, because of poor bone preservation we have no stature data for Morning Thorpe, and the pathology data are limited to teeth (Green et al., 1987: 189). Bradley Hull's (2007: 149-56) isotopic analysis identified limited dietary difference, but he was only able to acquire data from twenty-two individuals. The most convincing difference in $\delta 15 \mathrm{~N}$ levels existed between the wealthiest and the poorest graves, where the poorest graves showed the greatest variation. This is similar to the patterns visible in Chapter 5, in that the individuals without gravegoods or with smaller numbers of gravegoods showed the most variation between them, and the individuals with most artefacts had the least variation in their diets. Unfortunately, the numbers involved were small, but this also did correspond with the outlines of the plots, because the wealthiest burials were mostly found within two burial areas. It is therefore probable that the attitude difference was also supported by different lifeways between burial areas within this cemetery.

\section{The repertoire of mortuary syntax at Lechlade: a material and biological approach}

Lechlade is situated in the Upper Thames Valley, Gloucestershire, and archaeological rescue excavation took place in the summer of 1985 . The cemetery consisted of 223 skeletons in 200 grave cuts, as well as twenty-nine cremations, and can be split into two phases, the late-fifth and sixth century and the seventh century AD (Boyle et al., 1998; 2011). Lechlade has been referred to throughout the book, but not discussed in detail. Unlike many of the previous case studies, Lechlade was big and complex with multiple phases. It was the result of a plurality of simultaneous, continuous and broken narratives, and therefore the syntax at this site appears to be muddied and complex. It is therefore advantageous to consider the cemetery alongside the whole repertoire of mortuary devices employed in it.

The graves at Lechlade came from two distinct phases and can be understood on the basis of orientation, stratigraphy and datable gravegoods (Boyle et al., 1998: 49; 2011: 129; Figure 6.8). As a result there were enough burials to treat the furnished and the final-phase burials 


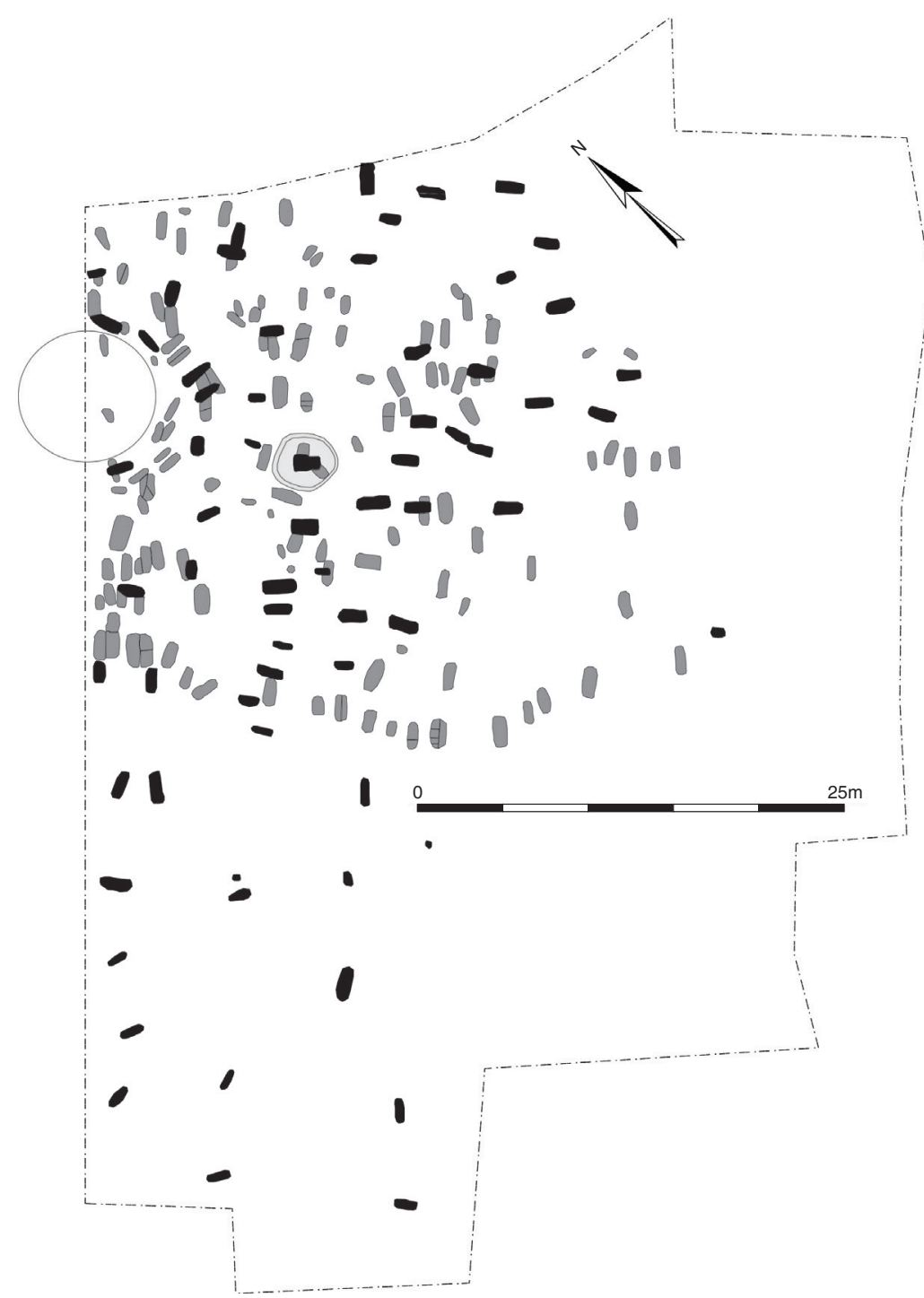

Figure 6.8 Lechlade, Gloucestershire, was split into two phases: grey are fifth/ sixth-century graves and black are the seventh-century graves.

separately. The Ripley's $\mathrm{K}$ statistical assessment indicates that there was significant clustering at $0.75 \mathrm{~m}$ for the fifth- and sixth-century burials and at $8 \mathrm{~m}$ for seventh-century burials (Sayer and Wienhold, 2012). The fifth- and sixth-century graves seem to have been organised into three burial plots, a northern, a southern and an eastern plot (Figure 6.9). The northern (A) and southern (B) plots were positioned on 


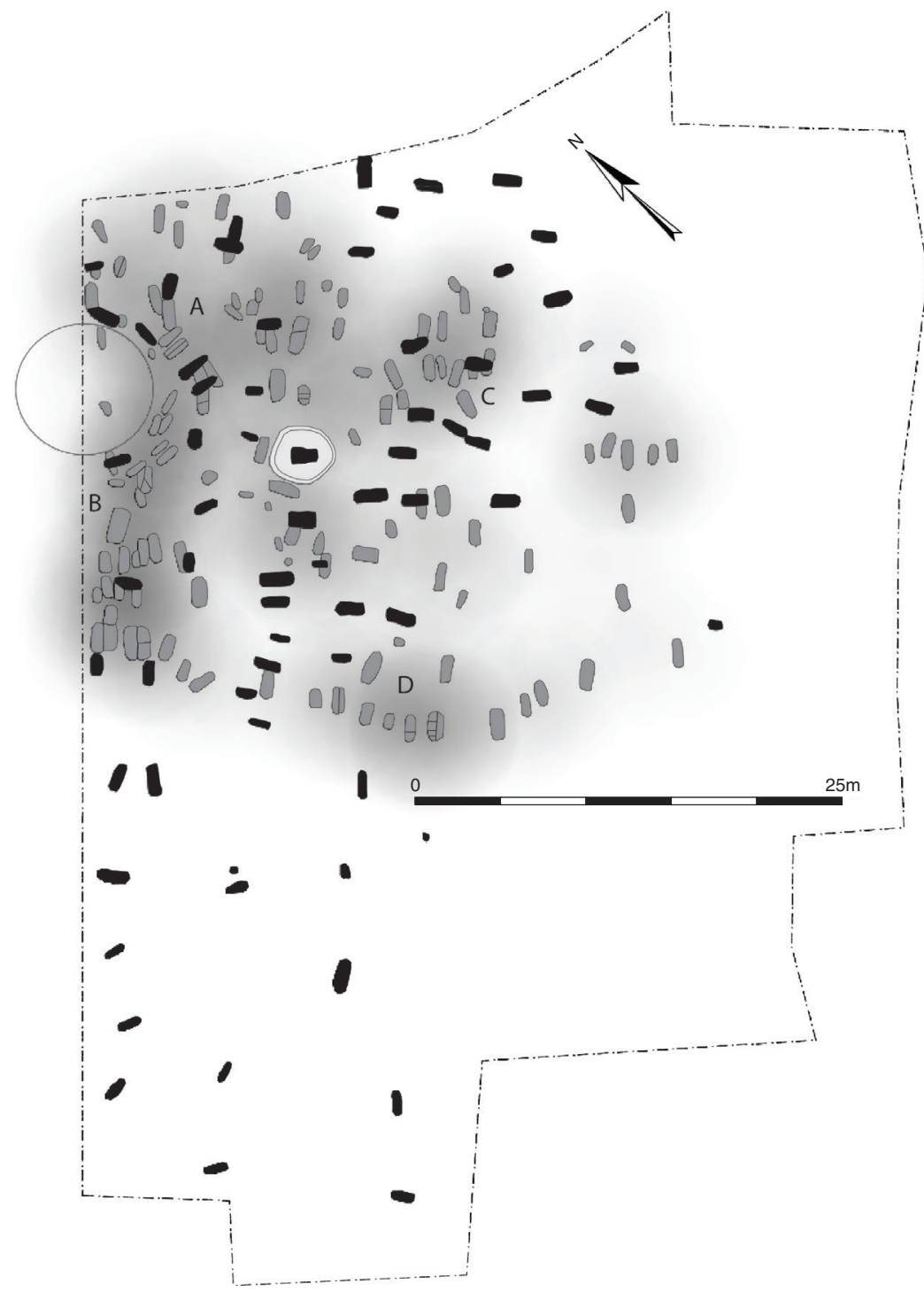

Figure 6.9 Lechlade, fifth- and sixth-century graves with kernel density set at $5 \mathrm{~m}$ to highlight the clustering of the graves. The Ripley's $\mathrm{K}$ analysis identified significant clustering between $0.75 \mathrm{~m}$ and $8 \mathrm{~m}$.

either side of a Bronze Age barrow to the west of the site, and the density of these graves seen with Ripley's $\mathrm{K}$ analysis makes this area seem to be a continuous group of burials. However, the wealthy graves were clustered to the south of the southern group and to the middle of the northern group, and the Bronze Age barrows separated these two zones, 
one to the north-east and one to the south-east. The eastern plot $(\mathrm{C})$ was isolated, with a visible gap in the density of inhumation graves between those graves to the west and to the east of the site. It was also the only plot that contained both types of burial ritual in significant numbers, suggesting that this group was purposely internally divided using inhumation or cremation burial. Consequently, in this first phase the spatial organisation and topography of the site was its primary organising element, and the selection of inhumation or cremation was the result of a localised attitude to the treatment of the dead, which subsequently distinguished the internal groups.

The final-phase burials had a notably sparser distribution and were some ten times less dense than for the earlier phase. The densest concentration of graves was to the north of the site, and these graves were primarily oriented on an E/W axis; interestingly, they create a Y-shape based on their density (Figure 6.10). This orientation and their location within the bounds of the fifth- and sixth-century cemetery contrasted with a series of multiple-orientation graves interred to the south of the site. It is also notable that this southern group contained very few artefacts. Moreover, the later-phase weapon graves were all located to the north.

Lechlade was a complex cemetery and at least initially does not appear to have had the 'kind of spatial or linear succession that has been used to phase cemetery development elsewhere' (Boyle et al., 2011:129). However, the site did employ a combination of modes of burial from the repertoire of mortuary syntax available throughout the early AngloSaxon period. This repertoire included different burial plots, different rituals, and organisation around earlier barrow monuments. Each of these technologies had been employed differently, suggesting that they were using specific semantic knowledge - this division of three groups within the early phase suggests an inherited rite specific to a societal subgroup, each one deliberately differentiated within the cemetery space while still part of the larger cemetery. In the seventh century, the number of groups decreased and the densely clustered plots were abandoned in favour of structured but dispersed placement of $\mathrm{E} / \mathrm{W}$ oriented burials. The core part of this cemetery remained in the north, within the boundaries of the sixth-century cemetery, but some new unfurnished graves were placed deliberately outside the sixth-century boundaries and to the south of the site.

The excavators identified some biological evidence that, they argued, suggests related people were buried in close proximity (Harman, 2011: 48) - for example, three of the four people with asterionic ossicles (burials 95/1, 170, and 105) were all near to each other. Burial 95/1 was a later-phase female burial, aged between 35 and 40, with a gold 


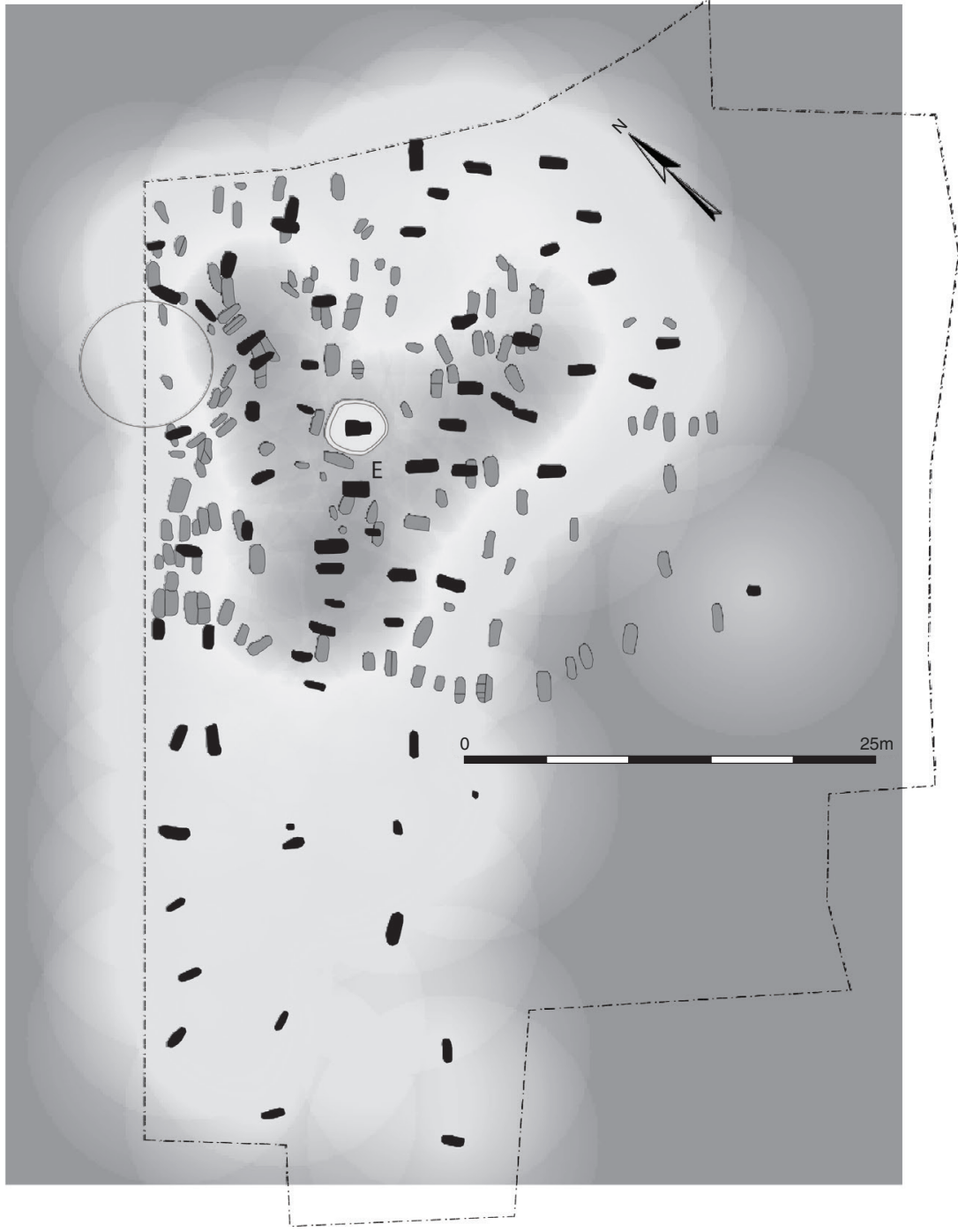

Figure 6.10 Lechlade, seventh-century graves with the kernel density set at $8 \mathrm{~m}$. Note the ' $Y$ ' shape created by this density plot; the male weapon burials were predominantly found at the top left arm of the Y.

disc pendant and with a long spearhead that had been converted into a weaving baton found at her waist, which was not the usual place for a spearhead in the grave. Burial 170 was of an adolescent with an undatable knife, and 105 was a young man aged between 16 and 18 and found with a large leaf-shaped spearhead. Inhumations 78, 104 and 115 all had sacral spina bifida occulta, and 78 and 115 also had an extra 
sacro-lumbar vertebra. Notably, grave 78 had a pair of decorated saucer brooches dating it to the middle-sixth century (Hines and Bayliss, 2013: $367,221)$. Burials 114 and 115 both had separate acromion process on the left-hand side (Harman, 2011: 48). From this study the height data detailed in Chapter 5 also indicated that there were strong degrees of biological relatedness within the cemetery.

In Chapter 5 we identified group D, which consisted of a row of graves and a few burials which were satellite to that. There were only two males with available height data, both weapon burials, $35(1.77 \mathrm{~m})$ and $92(1.74 \mathrm{~m})$. Unfortunately, grave 35 was not datable, whereas 92 contained an early spear and shield-type putting it into the first half of the sixth century. Remarkably, five of the biologically female burials were within $3 \mathrm{~cm}$ of each other's height - graves $18(1.6 \mathrm{~m})$, 81/1 (1.6 m), 81/4 (1.6 m), 165 (1.59 m) and 167/2 (1.58 m). Grave 18 was aged between 25 and 35 and contained saucer brooches and a great square-headed brooch, dating it to the early/middle-sixth century. Inhumation $81 / 4$ was in the same range, and may have been earlier than grave 18; based on a pair of relatively plain disc brooches, it may have dated to the later-fifth or early sixth century. Female burial 165 was aged between 20 and 25 and contained a small buckle, and 167/2 was also a young woman, aged between 19 and 22, found with two annular brooches and a copper ring.

Notably, the male weapon burials of the later-sixth- or seventhcentury phase were all located in the north of the cemetery and were much more homogeneous than the non-weapon graves from the same phase (Figure 5.29). Certainly, the five weapon graves - $40(1.72 \mathrm{~m})$; 104 (1.72 m); 155 (1.73 m); 172/3 (1.73 m); and 181 (1.72 m) - were all within $1 \mathrm{~cm}$ of each other in height. Grave 40 contained an adult male aged between 30 and 35 and two small spears; the older adult in grave 104, aged between 40 and 45, connected this group with the young woman in grave 78 and with the earlier male weapon burial 115, who was incidentally $1.73 \mathrm{~m}$ tall. Like 78 and 115 , the 30 - to 35 -yearold male in 172 also had an extra vertebra. Burial 155 was also aged between 30 and 35, and was buried with a seax and spearhead. The occupant of grave 181 was aged over 45 , and had an additional vertebra and asterionic ossicles on the right-hand side of his skull. He was found with a spearhead, bone pin and knife.

Among these later-phase weapon burials there were three outliers whose heights were significantly different from the others - the adult male in grave 106 was aged between 40 and 45 years and was buried with a spear and shield boss; he was $1.63 \mathrm{~m}$ in height. The male in grave 178 was $1.65 \mathrm{~m}$ tall and over 45 years in age, and he was found with a seax and knife. Grave 121 contained a very tall individual, at $1.83 \mathrm{~m}$, 
with a knife and small spearhead. Although not a completely homogeneous group, these later weapon burials were remarkably standardised. Indeed, across both the first and second phases the weapon burials were much more homogeneous than the non-weapon burials and the furnished female burials. As we saw in Chapter 5, the interquartile group of weapon graves ranged between $1.70 \mathrm{~m}$ and $1.74 \mathrm{~m}$ in height, with an average of $1.72 \mathrm{~m}$. The interquartile group of non-weapon graves ranged between $1.69 \mathrm{~m}$ and $1.77 \mathrm{~m}$, and also had a $1.72 \mathrm{~m}$ average, but with much more internal variety. Notably, though the weapon burials contained a core group with very similar heights, there were also a number of outliers. Evidently biological kinship was not the only qualification necessary for weapon burial, and importantly the weapon graves themselves varied tremendously in their material composition with seaxes, small spearheads and long spearheads. Some also included shields and/or other material culture.

\section{Material and textual perspectives on Anglo-Saxon kinship}

The early Anglo-Saxon cemeteries at Morning Thorpe and Lechlade illustrate very nicely how sites could use a variety of different methods and techniques to convey complex, but similar, messages. The biological data from these sites, and those discussed in Chapter 5, imply a very strong kinship element within these cemeteries. While there were almost certainly a number of biological relationships within these communities, the strongest evidence points to similarity between weapon burials found within particular burial areas. Chapter 5 also pointed to a number of female burials with similar heights, and these were in different burial areas. Indeed, the most similar females were found in the less wealthy burial areas at Great Chesterford, Worthy Park area A and Lechlade area $\mathrm{E}$.

The English Anglo-Saxon scholarly tradition has, since the nineteenth century, assumed a role for the family and kinship in early Anglo-Saxon England. Authors like John Kemble (1849), Charles Elton (1890) and Frederic Seebohm (1905) described Anglo-Saxon society as small-scale, locally based and tribal. They used descriptions that had all of the geographic conformity you might expect from larger national societies, including a central unifying administration. The early AngloSaxon cemeteries we have discussed in this book were not standardised, and contained considerable amounts of internal variation. The most obvious of these was the opposition created by the cemeteries that contained a small number of roughly equal groups - for example, Wakerley or Berinsfield - versus the cemeteries with differences in hierarchy or 
attitude evident in their use of space or their approach to chronology, such as Apple Down or West Heslerton. The contemporary written sources described at the beginning of this chapter suggest that the paternal kindred took priority in legal guardianship of inheritance, which implied a degree of patrilocality among the social elite. The implication is that Anglo-Saxon women travelled for marriage and that if the marriage broke down or the husband died she would return to her family to rear her child. Certainly, the cemetery data seem to support this: the tooth metrics and the height data point towards more homogeneity within the male populations than in the female populations, which would be expected in a patrilocal society where women from different kinship groups moved into a community each generation for marriage.

However, this is not the only story. Some cemeteries - like West Heslerton, Broughton Lodge, Castledyke, Norton and Sewerby - had a distinctly female-gendered character because more female graves contained gendered objects than male graves. This might imply that these communities contained women who maintained a strong sense of gender identity across several generations. Alternatively, given that West Heslerton had a series of male weapon graves at the core of plot A, it could imply that the male weapons grave and gender identity were reserved for a specific group of people. Indeed, the female height data from Great Chesterford, Worthy Park and Lechlade, and the tooth metric data from Eastry, Polhill, Oakington and Hatherdene, indicate that there were female biological relationships, that there were more of these and they included fewer people than the male kindred. Perhaps the seventh-century legal documents only describe the male elite family. Moreover, this pattern may in archaeology data suggest that there were different residency patterns depending on your social attitude.

According to the laws discussed above, the Anglo-Saxon family seems to have been at the core of the community, and important heads of families were also heads of the extended households that made up the local and regional elite. Elite marriage patterns and the law surrounding inheritance and kinship relationships seem to have assisted the protection of a specific lineage at the core of community. These kin married across similar families, and women moved for marriage, evidenced by their return in the case of divorce or bereavement. Nevertheless, the chronological information from Berinsfield, Deal or Apple Down seems to imply that men or women were buried in core areas within these cemeteries with one or two of each gender per generation. Perhaps women could be the heads of the household in their own right, or in the case of the death of the male head. It would be interesting to know who these women were. Were they the sisters of male kindred, or their daughters as the Anglo-Saxon wills suggest? Probably both, depending on localised 
circumstance. But a household did not just consist of its leaders; it was supported by family who remained locally within the extended family. Who were these people? Unmarried women, women whose husbands had moved into their community for marriage, brothers, cousins, elderly relatives? Perhaps ancient DNA evidence can tell us more about the elite Anglo-Saxon female - but we must also be aware that DNA is determined by biology, and it is social relationships that drive household prosperity. Indeed, a large part of the anthropology of relationships studies fictive kinship that might include fostering, adoption and other ways of creating relations (Carsten 2004).

At West Heslerton, Westgarth Gardens, Broadway Hill, Winterbourne Gunner and Lyminge II, burial areas with wealthier gravegoods also included the densest concentration of inhumations. These areas displayed the most gender disparity among them, even going so far as to separate male- and female-gendered graves into different spaces within the core burial area. That the emphasis of mortuary expression was on family is perhaps evidenced by the location of more children at Orpington, Apple Down and Westgarth Gardens in these core areas, or as satellite graves around barrow burials. Among these families, gender was important because it helped to determine social rules of inheritance, courtship and power.

In their mortuary treatment the members of less well-furnished areas placed less emphasis on chronology, on children's graves and on gender display. It is important that, at least where the evidence is available, there was stronger biological similarity between women in these areas. Perhaps some of these people, whose lifeways may have exposed them to more risk of skeletal trauma, did not routinely practise patrilocality, and residency may have varied or even favoured women who stayed within the wider extended community. Perhaps these people's households were secondary, the daughters or brothers of the primary house, the families and households of reeves, smiths or other significant members of the community. Notably, the core burial at West Heslerton plot B contained a man buried with metalworking tools, not weapons. Additionally, a third group is evident via the unstructured burial areas at Lechlade, Buckland, West Heslerton, Apple Down and Polhill. These groups may be better described as tertiary burial areas, and these contained the least gravegoods of all, along with the most biological diversity. These areas do not seem to have had a continual narrative associated with their burials.

Mortuary attitude and the different visual aesthetics described above underpinned differences in lifeways and in the attitude towards the expression of ancestry within the mortuary space. Perhaps the people in the lower-wealth areas of a cemetery did not need (or use) a lineage 
or key ancestors as part of the construction of their identity. Frederic Seebohm described early Anglo-Saxon 'households [which] might quite possibly be, from the first, embryo manors with serfs upon them. They might be settlements precisely like those ... [manorial estates] described by Tacitus' (Seebohm, 1905: 366). This interpretation was of its time and was situated within a cultural-historical or social evolutionary paradigm. Nonetheless, the two different types of cemetery -1 . those with two or more similarly sized, broadly equal groups with similar lifeways, and which contained primary or secondary burial areas; and 2. those cemeteries with a burial area that had some internal structuring, for example a core area, as well as a spectrum of other areas without similar structure that might include primary, secondary and tertiary burial areas - might imply different ways to organise an early AngloSaxon estate: either relying primarily on family and their households, as in type 1 , or including a greater diversity of households and people, with type 2 . Notably, these type 2 cemeteries became more common in the seventh century (Sayer, 2009), with a change in emphasis towards the ego-centred burial style without gravegoods and under small barrows, alongside unstructured zones which did not emphasise the individual. These second-phase cemeteries seem to have included more social stratification, and perhaps the greater stratification in the seventh century created heightened social tensions which can be witnessed by the presence and extent of grave robbery evident in large, stratified cemeteries in Kent, for example Bradstow School, Ozengell, St Peters or Finglesham (Klevnäs, 2013).

\section{Conclusion}

The early Anglo-Saxon era was one of the most dynamic periods in Britain's past. For some locally or regionally important families, the emphasis of mortuary ritual was on reinforcing kinship identities and reproducing family narratives in the ordering of antecedents into lineages. These ancestral landscapes were used to display and legitimise narratives around social stratification and elite identities locally, and for a regional network who used feud and marriage to reinforce male lineage and property ownership. This was the Anglo-Saxon family, patrilocal, hierarchical but ultimately flexible, with male and female heads of household as needed. The cemetery evidence suggests that the household was a diverse place, containing a multiplicity of different lifeways, burial styles and ways to express identity. Notably, however, there were scales of expression from the person created with a connection or emotional bond via the objects selected for inclusion, the dressing of the corpse, and the positioning of the body or the construction of the wooden pyre 
or earthen grave. The household might be explored by way of the location of burial, the use of space, its orientation, cremation or inhumation, or by differential density and the use of rows of graves. Interestingly, the objects usually associated with ethnicity seem more comfortably situated within familial or household, rather than regional, identities. Indeed, it may not be possible to see regional ethnicity at all, because by far the most important organisational principle seems to be local situation. Ultimately, it is the archaeologist and historian who have framed the Early Middle Ages in that mode; whereas Anglo-Saxon cemeteries, stories, laws and poetry were about family, personal relationships and belonging.

Family was expressed in the mortuary space using chronologically contingent narratives, which may have included returning to a space repeatedly or building small barrows for key members of each generation. For some people, mortuary behaviour conveyed family attitude in the expression of gender identity and attitude towards ancestors and children. This was more keenly conveyed among the core burials of the early Anglo-Saxon family than the plain inhumations of their dependants. Children and infants were treated differently by the family, more often located next to core areas, or around individual antecedents within family spaces than in the wider household areas. Ultimately, AngloSaxon burial practice was about the expression of identity, hierarchy and group belonging; not via wealth or gravegoods, which may have been contingent on time, place and person, but by utilising the mortuary performance, and the variety of mortuary technologies available to create, recreate and perform community narratives. These narratives were supposed to be understood via the aesthetics of mortuary space, and the construction of semiotic language. They were meant to be understood by multiple participants at the graveside, at the burial, days later at the funeral or years later as community members returned to the site to tell stories about themselves and their past. They were meant to be understood because they were designed to carry community narratives. Stories about the dead and the living, who they were and what they did. These narratives can be understood by archaeologists because we are simply latecomers to the mortuary drama. With the use of contextual, holistic, multi-scalar and multi-dimensional approaches, it is possible to see some small part of the narratives that these sites conveyed. 